\title{
高濃度の $\mathrm{S}_{2} \mathrm{O}_{3} 2$-を含む高塩類、高 $\mathrm{COD} の$ 写真廃液に増殖可能な硫黄酸化細菌污泥の 馴養及びこの污泥を用いた廃液処理特性
}

\author{
Acclimation of Sulfur-Oxidizing Bacteria to Photo-Processing Waste Containing \\ High-Strength Thiosulfate, Salinity, COD and the Waste Treatment Performance \\ by the Acclimated Bacteria
}

林 涁勒、細見正明、村上昭彦

\author{
東京農工大学工学研究科物質生物工学専攻 \\ 厂184 東京都小金井市中町2-24-16
}

BIN LE LIN, MASAAKI HOSOMI and AKIHIKO MURAKAMI

Department of Chemical Engineering, Tokyo University of Agriculture

\& Technology 2-24-16, Nakamachi, Koganei-Shi, Tokyo, 184 Japan.

\begin{abstract}
Establishing a treatment process for practical, economic disposal of photo-processing waste (PW) has become an urgent environmental concern under recently enacted revisions of London Treaty. This paper describes the acclimation of sulfur-oxidizing bacteria (SOB), and the PW treatment performance by acclimated $\mathrm{SOB}$ in conjunction with granular activated carbon (GAC), which demonstrates as an effective biological treatment method.

No distinct difference in acclimating SOB to strong dilution of PW (50-times to 12-times dilution) was observed between two acclimation methods, i.e., using diluted PW directly and using ONM medium firstly to accumulate SOB. Comparison of SOB/GAC and SOB acclimation systems for further acclimation (10-times to 3-times dilution), demonstrated that SOB/GAC system succeeded in acclimating SOB to 3-times diluted PW, while SOB system failed in even 6-times dilution. Meanwhile, culture of SOB in various dilutions of calcination PW system and inorganic salts of $\mathrm{PW}$ composition system clarified that $\mathrm{SOB}$ can grow even on solution of raw $\mathrm{PW}$ containing $12 \%$ salinity.

Weak dilution of $\mathrm{PW}$ (5-times to 4-times dilution) was treated by using SOB in conjunction with $10 \mathrm{~g} / l \mathrm{GAC}$ in a long-term $(98 \mathrm{~d})$ continuous treatment (HRT=1.9-7.7 d) such that massreduced sulfur compounds were completely oxidized to sulfate, while biodegradable organics in dissolved organic carbon (DOC) were simultaneously degraded at a removal rate of $55 \%$, and resulted in $68 \%$ removal rate in chemical oxygen demand (COD).

Selective culture of the SOB sludge by using seven kinds of medium revealed that about $90 \%$ of the SOB was facultative chemoautotrophic bacteria and also two kinds of heterotrophic bacteria were present.

Key words : Acclimation, Facultative chemoautotrophic bacteria, Granular activated carbon, Heterotrophic bacteria, Photo-processing waste, Sulfur-oxidizing bacteria, Salinity, Thiosulfate oxidation.
\end{abstract}




\section{1.はじめに}

写真廃液は高濃度の還元性硫黄化合物、高濃度の塩類、 COD、荎素を含み、かつ生物的に難分解性や阻害性のあ る現像主薬などが多く含まれている廃液である ${ }^{1-3)}$ 。従 来では、回収業者は廃液中の銀を回収してから海洋投棄 を行ってきた ${ }^{1,4)}$ 。しかし、『廃棄物などの投棄による 海洋污染の防止条約』であるロンドン条約の改正を受け、 1996年 1 月 1 日以降は海洋投棄が全面禁止されることに なり、除去効率の良い、コストの安い、実用性の高い陸 上における処理プロセスの研究開発は社会的急務となっ ている。

写真廃液処理に関する既往の研究は、物理処理 ${ }^{6-8)}$ 、 化学処理 ${ }^{9-13)}$ と生物処理 ${ }^{14-19)}$ と複合処理 ${ }^{1,4,20)}$ に分けら れる。物理処理及び化学処理では処理効率は良いものの、 コストが極めて高いという問題があるため、コストの低 い生物処理が注目されてきた。しかし、従来の生物処理 では写真廃液のCODを80 90\%除去するのに、10 100 倍の大量希釈、15～50日の長い処理期間を必要としたた め、装置の大型化や高い運転コストが問題となっている。 また、複合処理は 2 例報告されているが、除去効率、経 済性及び実用性において種々の問題があった。膜分離高 濃度污泥処理一オゾン処理一浸漬ろ床法との複合処理方 法では、写真廃液を10 60倍希釈でTOC (全有機酸素) 78\%、COD96\%除去できたと報告されているが、膜分離 高濃度污泥法と浸漬乃床法には運転管理面での技術的な 問題があり、オゾン処理とを組み合わせた実用装置では 複雑でランニングコストが高くなると指摘されている。 また、フェントン処理一活性污泥処理との複合処理方 法 $^{20)}$ では、写真廃液のCODを83 92\%除去するには大量 の過酸化水素 $\left(\mathrm{H}_{2} \mathrm{O}_{2}\right)$ 及び大量の希釈 $(30 \sim 100$ 倍) を 必要とし、窒素の除去については検討されなっかた。

著者らは、写真廃液処理の実用化プロセスに関する一 連の研究を行っている。 $\mathrm{H}_{2} \mathrm{O}_{2}$ のみを加え、 $\mathrm{H}_{2} \mathrm{O}_{2}$ 処理一 有機物質除去・硝化一脱窒という処理効率のよい複合処 理プロセスを提案した ${ }^{3)}$ 。しかし、このプロセスでは、 廃液 $1000 \mathrm{~m} l$ 対して $670 \mathrm{~m} l$ も $30 \% \mathrm{H}_{2} \mathrm{O}_{2}$ を必要とし、 $\mathrm{H}_{2} \mathrm{O}_{2}$ のコストが問題となる。また、 $\mathrm{H}_{2} \mathrm{O}_{2}$ を廃液中に加 えた時に、大量のガスが発生するとともに激しく沸騰す るため、実処理においては突沸の危険性が予想される。

写真廃液の $\mathrm{H}_{2} \mathrm{O}_{2}$ 処理に扔ける主な $\mathrm{H}_{2} \mathrm{O}_{2}$ 消費反応は次 の 3 つが考えられる。

(1) 大量の $\mathrm{S}_{2} \mathrm{O}_{3}{ }^{2-} 、 \mathrm{SO}_{3}{ }^{2-}$ 等の還元性硫黄化合物の 酸化
（2） 酶酸等の易分解性有機物質の無機化

（3）ヒドロキシルアミン、EDTA等の難分解性現像 主薬の易分解性化

特に写真廃液中の大量の $\mathrm{S}_{2} \mathrm{O}_{3}{ }^{2-} 、 \mathrm{SO}_{3}{ }^{2}$-等の酸化は次 の反応式により、大量の $\mathrm{H}_{2} \mathrm{O}_{2}$ が消費すると同時に、大 量の反応熱が放出すると考えられる。

$$
\begin{aligned}
& 2 \mathrm{~S}_{2} \mathrm{O}_{3}{ }^{2-}+\mathrm{H}_{2} \mathrm{O}_{2} \rightarrow \mathrm{S}_{4} \mathrm{O}_{6}{ }^{2-}+2 \mathrm{OH}^{-} \\
& \mathrm{S}_{4} \mathrm{O}_{6}{ }^{2-}+7 \mathrm{H}_{2} \mathrm{O}_{2} \rightarrow 4 \mathrm{SO}_{4}{ }^{2-}+6 \mathrm{H}^{+}+4 \mathrm{H}_{2} \mathrm{O} \\
& \mathrm{S}_{2} \mathrm{O}_{3}{ }^{2-}+4 \mathrm{H}_{2} \mathrm{O}_{2} \rightarrow 2 \mathrm{SO}_{4}{ }^{2-}+2 \mathrm{H}^{+}+3 \mathrm{H}_{2} \mathrm{O} \\
& 3 \mathrm{SO}_{3}{ }^{2-}+2 \mathrm{H}_{2} \mathrm{O}_{2} \rightarrow 3 \mathrm{SO}_{4}{ }^{2-}+2 \mathrm{H}^{+}+\mathrm{H}_{2} \mathrm{O}
\end{aligned}
$$

そこで、これらの大量の $\mathrm{S}_{2} \mathrm{O}_{3}{ }^{2-}{ }^{2} \mathrm{PSO}_{3}{ }^{2}{ }^{2-}$ のような無機性 還元物質、及び酶酸等の易分解性有機物質を、低い希䣋 倍率で先に微生物により酸化処理すれば、それに続く化 学処理での $\mathrm{H}_{2} \mathrm{O}_{2}$ 使用量が大幅に削減できるとともに、 突沸の危険性も克服できると思われる。本報では高濃度 の写真廃液中に増殖可能な硫黄酸化細菌（SOB）污泥の 馿養、及びこのSOB污泥を用いた廃液の連続処理結果、 SOB污泥の菌組成について報告する。

\section{2. 実験及び方法}

\section{1 供試写真廃液}

本実験では一般的に使用される現像廃液と定着廃液を 体積比 $1 ： 1$ で混合したモデル写真廃液を供試廃液とし た ${ }^{2,3)}$ 。供試廃液の主な特徵は以下に挙げられる。

1. $\mathrm{pH} 8.8 \sim 9.2$ 黒褐色液体であり、強いアンモニア 臭 $\left(\mathrm{NH}_{4}-\mathrm{N}\right.$ として約 $10,000 \mathrm{mg} / l$ 含む) を有してい る。

2. $\left(\mathrm{NH}_{4}\right)_{2} \mathrm{~S}_{2} \mathrm{O}_{3} 、 \mathrm{Na}_{2} \mathrm{~S}_{2} \mathrm{O}_{3} 、 \mathrm{Na}_{2} \mathrm{SO}_{3}$ などの塩類濃度が 高く、約 $12 \%$ である。

3．還元性物質として $\mathrm{S}_{2} \mathrm{O}_{3}{ }^{2-}$ は約 $35,000 \mathrm{mg} / h 、 \mathrm{SO}_{3}{ }^{2-}$ は約3, 000 6, $000 \mathrm{mg} /$ にを含んでおり、ヨウ素消費量 は 56,000 60, $000 \mathrm{mg} /$ lである。

4. $\mathrm{COD}_{\mathrm{Mn}}$ は約 $38,000 \mathrm{mg} /$ lと極めて高い。このうち還元 性硫黄化合物に依存している無機性CODは約50\%を占 めている。

5.ヒドロキシルアミン、フェニレンジアミン、フェニ ドン、EDTAなどの難分解性かつ生物阻害性のある有 機物質を多く含み、生物分解性の指標値BOD/COD $\mathrm{CD}_{\mathrm{Mn}}$

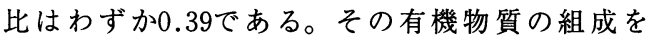
Table 1 に示す。 
Table 1 Organic compounds contained in model PW

\begin{tabular}{l|c||c|c}
\hline \multicolumn{1}{c|}{ Organic compound } & Ratio $(\%)$ & Organic compound & Ratio $(\%)$ \\
\hline Hydroquinone & 21.8 & $\rho$ phenylene diamine & 2.1 \\
\hline Acetic acid 90\% & 18.4 & $\rho$-toluenesulfonate sodium & 1.9 \\
\hline 5 -sulfosalicylic acid dihydrate & 14.5 & Tartaric acid & 1.6 \\
\hline EDTA - Fe & 7.5 & Surface active agents & 1.7 \\
CD-3, CD 4 & 5.7 & Aminopolycarboxylic acid & 1.4 \\
\hline Heterocyclic compounds & 4.9 & Hydroxylamine & 1.0 \\
\hline Triethylene glycol & 3.5 & EDTA & 0.6 \\
\hline Diethylene glycol & 3.5 & Glutaraldehyde & 0.5 \\
\hline Boric acid & 3.3 & Formalin & 0.3 \\
\hline Chelating agents & 1.7 & Phenydone & \\
\hline Benzyl alcohol & 2.5 & Triethanol amine & 0.3 \\
\hline
\end{tabular}

\section{2. $2 \mathrm{SOB}$ 污泥の馴養}

写真廃液の高い塩類濃度、しかも変動しやすい特徴を 考慮し、塩類濃度の変動に耐えやすい微生物群が存在し ていると思われる多摩川河口域底泥に注目し、植種源と して採用した。馿養実験は、全て 11 の回分装置を用い て、 $25 \pm 1{ }^{\circ} \mathrm{C}$ の恒温室にて曝気による培養を行った。な お、污泥の馴養の判断は $\mathrm{SO}_{4}$-Sの生成量、 $\mathrm{pH}$ の変化に より評価した。馴養方法は、下記の 2 通りを検討した。

\section{2 .1 培地系と廃液系による佣養}

SOBの集積培養によく使われるONM培地 ${ }^{21)}$ (培地系) と50倍希釈した供試廃液（廃液系）を用いて、河口域の 底泥を約 $20 \mathrm{~g} /$ の割合で植種し、SOBの集積培養と廃液 馴養を始めた。ONM培地の組成をTable 2 に示す。

1 日 1 回 $\mathrm{pH}$ 測定し、 $\mathrm{pH}$ の低下が認められなくなっ
た時点で、その培養液中の $\mathrm{S}_{2} \mathrm{O}_{3}-\mathrm{S} 、 \mathrm{SO}_{4}$-Sを測定した。 $\mathrm{S}_{2} \mathrm{O}_{3}$ - $\mathrm{S}$ が完全に $\mathrm{SO}_{4}$-Sに酸化されたことを確認した後、 培養液加遠心集菌（6,000 rpm、15 min、 $4{ }^{\circ} \mathrm{C} ）$ し、更 に高濃度の供試廃液中に植菌して馿養を行った。このよ うに、培地系ではONM集積培養 $\rightarrow 28$ 倍希釈 $\rightarrow 18$ 倍 $\rightarrow 13$ 倍 $\rightarrow 11$ 倍、廃液系では 50 倍希釈 $\rightarrow 30$ 倍 $\rightarrow 20$ 倍 $\rightarrow 15$ 倍 $\rightarrow 12$ 倍、順次に供試廃液の希釈倍率を低めながら馿養を行っ た。その後、培地系から得られたSOB污泥を用い、粒状 活性炭（GAC）馴養法を用いてより高濃度の廃液馴養を 検討した。

\subsection{2 $\mathrm{SOB} / \mathrm{GAC}$ 系および $\mathrm{SOB}$ 系による馿養}

難分解性廃液の生物処理において、活性炭の添加によ る促進効果があると多数報告されている ${ }^{21-25)}$ 。供試廃液 中には難分解性の現像主薬や生物阻害性のあるヒドロキ シルアミン、フェニレンジアミン等が多く含まれている

Table 2 Composition of ONM medium used for SOB enrichment

\begin{tabular}{cc}
\hline Constituents & Concentration $(\mathrm{g} / l)$ \\
\hline $\mathrm{Na}_{2} \mathrm{~S}_{2} \mathrm{O}_{3} \cdot 5 \mathrm{H}_{2} \mathrm{O}$ & $20.0\left(8.0^{*}\right)$ \\
$\mathrm{KH}_{2} \mathrm{PO}_{4}$ & 4.0 \\
$\left(\mathrm{NH}_{4}\right)_{2} \mathrm{SO}_{4}$ & 2.0 \\
$\mathrm{CaCl}_{2} \cdot 2 \mathrm{H}_{2} \mathrm{O}$ & 0.3 \\
$\mathrm{MgSO}_{4} \cdot 7 \mathrm{H}_{2} \mathrm{O}$ & 0.3 \\
$\mathrm{FeSO}_{4} \cdot 7 \mathrm{H}_{2} \mathrm{O}$ & 0.01 \\
Yeast extract & 0.5 \\
Glucose & 3.0 \\
Powdered agar & 15.0 \\
pH & 5.0 \\
\hline
\end{tabular}

${ }^{*}$ Only used in calcination system and selective culture of SOB sludge. 
ため、本実験では、10倍希釈廃液からの馴養において、 GACを $10 \mathrm{~g} / 1$ の割合で添加するSOB/GAC系とGACを添加 しないSOB系を用い、8 倍希釈 $\rightarrow 6$ 倍 $\rightarrow 4$ 倍 $\rightarrow 3$ 倍まで 順次希釈倍率を低めながら馴養を検討した。1 日〜2 日 に 1 回pHを測定し、培養液中の $\mathrm{S}_{2} \mathrm{O}_{3}-\mathrm{S} 、 \mathrm{SO}_{4}-\mathrm{S}$ 測 定した。

\section{3 SOB污泥の耐塩性についての検討}

供試廃液の塩類濃度は $12 \%$ 、その大部分は $\left(\mathrm{NH}_{4}\right)_{2}$ $\mathrm{S}_{2} \mathrm{O}_{3} 、 \mathrm{Na}_{2} \mathrm{~S}_{2} \mathrm{O}_{3} 、 \mathrm{Na}_{2} \mathrm{SO}_{3}$ などの還元性硫黄化合物によ るものである。SOB污泥の耐塩性を検討するため、下記 の 2 通りの方法でその耐塩性を評価した。

\section{3 .1 蒸発残渣実験系}

供試廃液中の難分解性および阻害性有機物質を含むあ らゆる有機物を除去するため、強熱 $\left(600^{\circ} \mathrm{C} 、 30 \mathrm{~min}\right)$ 処 理を行った。残った蒸発残渣 (無機塩類) にONM培地 （Table 2）を添加して、超音波を約 5 分間かけて均一に
混ぜた。この溶液の塩類濃度を供試廃液原液の塩類濃度 とした。この溶液 (無希釈) 及び、この溶液をONM培 地で 2 倍、 4 倍、 6 倍、 8 倍、10倍に希釈した計 6 系列 に、遠心集菌したSOB污泥（MLVSS $=740 \mathrm{mg} / l$ ) を均等 に植菌した。ONM培地のみの系を対照系とした。SOB污 泥の活性を $\mathrm{pH}$ 変化、 $\mathrm{SO}_{4}-\mathrm{S}$ の生成率、及び $\mathrm{S}_{2} \mathrm{O}_{3}-\mathrm{S}$ の 酸化率で検討した。

\section{3 .2 供試廃液組成の無機塩濃度を再現した無機塩成 分実験系}

2.3.1の方法では、供試廃液中の高濃度 $\mathrm{S}_{2} \mathrm{O}_{3}{ }^{2}$-など無 機性硫黄還元物質は強熱により、硫酸に酸化されたため、 供試廃液の組成成分中の無機塩のみ（Table 3）での実 験系を設けた。つまり、無機塩成分で作った溶液に有機 物質としてグルコース $(3.0 \mathrm{~g} / l)$ 、酵母エキス $(0.5 \mathrm{~g} / l)$ を加え、この溶液を2.3.1と同じように 6 系列に希釈し、 SOB污泥の活性を検討した（MLVSS $=860 \mathrm{mg} / l)$ 。希釈 にはグルコース、酵母エキスを含む溶液を用いた。

Table 3 Composition of inorganic constituents in simulated model PW made from typical constituents of developer and fix-stabilizer wastes (1:1 by vol.)

\begin{tabular}{|c|c|c|c|}
\hline \multicolumn{2}{|c|}{ Developer waste $(\mathrm{g} / \mathrm{l})$} & \multicolumn{2}{|c|}{ Fix-stabilizer waste $(\mathrm{g} / \mathrm{l})$} \\
\hline $\mathrm{Na}_{2} \mathrm{SO}_{3}$ & 4.3 & Ammonium thiosulfate $(70 \%)$ & $117.0 \mathrm{ml}$ \\
\hline $\mathrm{K}_{2} \mathrm{SO}_{3}$ & 21.7 & $\mathrm{Na}_{2} \mathrm{~S}_{2} \mathrm{O}_{3} \cdot 5 \mathrm{H}_{2} \mathrm{O}$ & 15.5 \\
\hline $\mathrm{K}_{2} \mathrm{CO}_{3}$ & 12.0 & Ammonium sulfite & 2.1 \\
\hline $\mathrm{NaHCO}_{3}$ & 1.0 & $\mathrm{Na}_{2} \mathrm{SO}_{3}$ & 2.5 \\
\hline $\mathrm{KOH}$ & 20.0 & $\mathrm{NaHSO}_{3}$ & 3.0 \\
\hline $\mathrm{NaOH}$ & 2.5 & Ammonium sulfate $(27 \%)$ & 17.5 \\
\hline $\mathrm{NH}_{4} \mathrm{Br}$ & 0.5 & Sulfuric acid & 1.3 \\
\hline \multirow[t]{8}{*}{$\mathrm{KBr}$} & 4.9 & Liquid ammonium (27\%) & 5.9 \\
\hline & & $\mathrm{NH}_{4} \mathrm{NO}_{3}$ & 1.3 \\
\hline & & Nitric acid $(67 \%)$ & 0.6 \\
\hline & & $\mathrm{Na}_{2} \mathrm{~S}$ & 0.04 \\
\hline & & $\mathrm{NaOH}$ & 3.4 \\
\hline & & $\mathrm{KCl}$ & 0.5 \\
\hline & & $\mathrm{NH}_{4} \mathrm{Br}$ & 3.3 \\
\hline & & $\mathrm{KBr}$ & 1.6 \\
\hline
\end{tabular}

\section{4 SOB/GAC系による供試廃液の連続処理}

回分装置を用いた馴養結果を踏まえて、GACを $10 \mathrm{~g} / \mathrm{l}$ 添加したSOB/GAC系（回分馴養で得られたSOB污泥を 用いた）による供試廃液の連続処理を行った。連続処理 は $25^{\circ} \mathrm{C} \pm 1{ }^{\circ} \mathrm{C}$ の恒温室にてFig. 1 に示した $3 l$ の処理装 置を用いた。
8 倍希釈廃液の処理からスタートし、主に 5 倍、 4 倍 希釈廃液を中心に処理を行った。連続処理においては、 流入廃液の $\mathrm{pH}$ 調整及び反応槽中の $\mathrm{pH}$ 制御は行わなかっ た。また、 2 日に 1 回流入廃液及び処理水をサンプリン グし、 $\mathrm{S}_{2} \mathrm{O}_{3}-\mathrm{S} 、 \mathrm{SO}_{4}-\mathrm{S} 、 \mathrm{DOC} 、 \mathrm{COD}_{\mathrm{Mn}}$ の濃度を定量し た。 


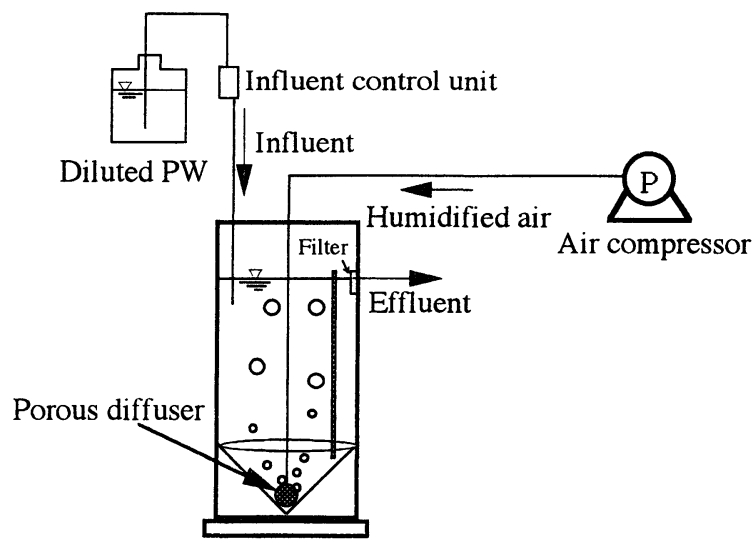

Fig. 1 Reactor system used for continuous treatment experiment.

\section{57 種類の選択培地を用いた単離実験}

SOB污泥の菌組成及び栄養性について、集積培養に使 用したONM培地を基礎培地 ${ }^{21)}$ として、Table 4 に示す 7 種類の選択培地を污泥の単離実験に用いた。7 種類の選 択培地をオートクレーブで滅菌し、シャーレに分注して 固化させた。連続処理実験（45日目）のSOB污泥を遠心 集菌（6,000 rpm、15 min、 $4^{\circ} \mathrm{C} ）$ した後、生理食塩水で $10^{-4} \sim 10^{-8}$ 倍に希釈した。希釈された菌液を $0.1 \mathrm{~m} l$ 寒天 培地に塗布し、 $25^{\circ} \mathrm{C} \pm 1{ }^{\circ} \mathrm{C}$ で 3 日間培養した。出現した コロニーの形態を観察・分類した。

\section{6 分析方法}

DOCは、全有機炭素分析計（島津製作所、TOC-500 型）を用いて分析した。COD $\mathrm{CN}_{\mathrm{Mn}} \mathrm{pH}$ 、及びMLVSSは、 下水試験方法 ${ }^{26)}$ に従って測定した。また、 $\mathrm{S}_{2} \mathrm{O}_{3}-\mathrm{S}$ 、 $\mathrm{SO}_{4}$ 一Sはイオンクロマトグラフ（横河、IC7000-E）を 用いて測定した。全てのサンプルはGF/Fガラスフィル ター（ポアサイズ $=0.8 \mu \mathrm{m}$ ) により滤過してから、分 析するまで $4{ }^{\circ} \mathrm{C}$ の冷蔵庫に保存した。

\section{3. 実験結果及び考察}

\section{3. $1 \mathrm{SOB}$ 污泥の馿養}

\section{1 .1 培地系と廃液系を用いた馿盖}

イオンクロマトグラフによる分析結果から、培地系と 廃液系との両系列による馴養では、供試廃液中の $\mathrm{S}_{2} \mathrm{O}_{3}$-Sは完全に $\mathrm{SO}_{4}$-Sに酸化され、 $\mathrm{pH}$ 热下した。
これはSOB污泥の働きによるものと示唆された。馿養期 間における pHの経時変化をFig. 2 に示す。各希釈系の $\mathrm{pH}$ の低下速度には、両系列の間に有意な差は認められ なかった。

\section{$3.1 .2 \mathrm{SOB} / \mathrm{GAC}$ 系および $\mathrm{SOB}$ 系による馿盖}

SOB/GAC系とSOB系との両系を用いた10倍、8倍、 6 倍、 4 倍及び 3 倍希釈廃液での馿養結果をTable 5 に 示す。そのうちの10倍、8 倍、6 倍希釈廃液までの $\mathrm{pH}$ 経時変化をFig. $3 、 \mathrm{~S}_{2} \mathrm{O}_{3}-\mathrm{S}$ と $\mathrm{SO}_{4}-\mathrm{S}$ 経時変化をFig. 4 に示す。

10倍と 8 倍希䣋廃液での馿養において、両系のpHは

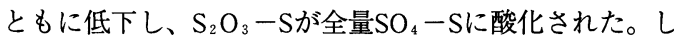
かし、SOB/GAC系の方ではpHが早く低下し、 $\mathrm{S}_{2} \mathrm{O}_{3}-\mathrm{S}$ も早く全量 $\mathrm{SO}_{4}$ 一Sに酸化された。これはGACが共存す るSOB污泥の酸化活性を促進したと考えられる。また、 6 倍希釈での馿養において、SOB系では約 2 週間の馿養 で、 $\mathrm{S}_{2} \mathrm{O}_{3}$-Sは $45 \%$ しか消滅しなかった。これに対して、 SOB/GAC系では約 1 週間でpHが 3 まで下がり、約 2 週 間の馿養で $\mathrm{S}_{2} \mathrm{O}_{3}-\mathrm{S}$ が完全に $\mathrm{SO}_{4}-\mathrm{S}$ 酸化され、 $\mathrm{SO}_{4}$ 一Sの生成率は $111 \%$ であった。このように、SOB系 では十分なSOB污泥の馿養が認められなかったのに、 SOB/GAC系では約 2 週間で馿養が認められた。これは 供試廃液中の毒性を持つ現像主薬などがGACにより吸着 されたため、SOB污泥の活性が阻害されなかったと考え られる。

また、 4 倍、 3 倍希釈廃液での馿養については、 $\mathrm{SOB} / \mathrm{GAC}$ 系では何れも供試廃液中の $\mathrm{S}_{2} \mathrm{O}_{3}-\mathrm{S}$ が全量消 滅し、馴養が認められた（Table 5)。しかし、 $\mathrm{SO}_{4}-\mathrm{S}$ 
Table 4 Observed colonies after selective culture (for three days) with seven kinds medium.

\begin{tabular}{|c|c|c|c|}
\hline Medium & \multicolumn{3}{|c|}{ Morphology of colony" } \\
\hline $\begin{array}{l}\text { 1. Inorganic-ONM } \\
\text { (Composition of Table } 2 \text { without yeast extract and glucose) }\end{array}$ & A & & \\
\hline 2. Inorganic-ONM+yeast extract $(1.0 \mathrm{~g} / l)$ & A & $\mathrm{B}$ & $\mathrm{C}$ \\
\hline 3. Inorganic-ONM + sodium acetate $(15 \mathrm{~g} / l)$ & A & $\mathrm{B}$ & \\
\hline 4. Inorganic-ONM+glucose $(4.5 \mathrm{~g} / l)$ & A & $\mathrm{B}$ & \\
\hline 5. Inorganic-ONM without $\mathrm{Na}_{2} \mathrm{~S}_{2} \mathrm{O}_{3}+$ yeast extract $(1.0 \mathrm{~g} / l)$ & & $\mathrm{B}$ & $\mathrm{C}$ \\
\hline 6. Inorganic-ONM without $\mathrm{Na}_{2} \mathrm{~S}_{2} \mathrm{O}_{3}+$ sodium acetate $(15 \mathrm{~g} / l)$ & & $\mathrm{B}$ & $\mathrm{C}$ \\
\hline 7. Inorganic-ONM without $\mathrm{Na}_{2} \mathrm{~S}_{2} \mathrm{O}_{3}+$ glucose $(4.5 \mathrm{~g} / l)$ & & $\mathrm{B}$ & $\mathrm{C}$ \\
\hline
\end{tabular}

${ }^{*}$ Colony-A : $0.5 \mathrm{~mm}$ in diameter, opaque, light yellow or white

Colony-B: $1.0 \mathrm{~mm}$ in diameter, opaque, light pink

Colony-C: $1.5 \mathrm{~mm}$ in diameter, transparent, milky white

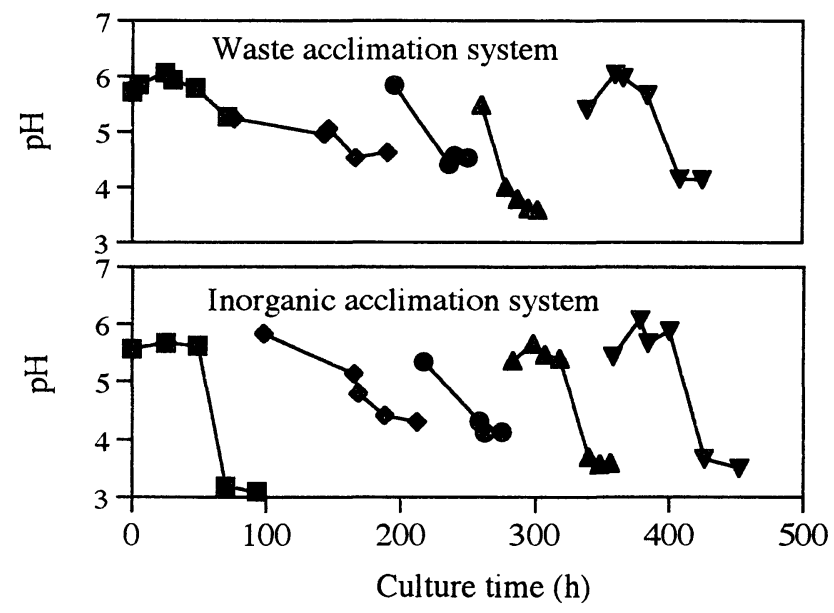

Fig. 2 Variations in $\mathrm{pH}$ during the SOB acclimation using the waste and inorganic acclimation systems. Symbols : $\square$, 50-times dilution (waste) and ONM (inorganic), , 30-times dilution (waste) and 28-times dilution (inorganic), 0, 20-times dilution (waste) and 18-times dilution (inorganic), 15-times dilution (waste) and 13-times dilution (inorganic), $\nabla, 12$-times dilution (waste) and 11-times dilution (inorganic)

の生成率はそれぞれ $82 \% 、 72 \%$ あった。これは一部の $\mathrm{S}_{2} \mathrm{O}_{3}{ }^{2-}$ が単体硫黄になって $\mathrm{SOB}$ の細胞内に蓄積したため と考えられた ${ }^{27)}$ 。また、 4 倍、3 倍希釈廃液中のGACは 6 倍希釈系と同じ添加量 $(10 \mathrm{~g} / l)$ であったため、阻害 性有機物質がすべてGACに吸着されず、液中に一部残っ ていた結果、SOB污泥の活性が阻害されたことも一因と 考えられる。

\section{2 SOB污泥の耐塩性}

\section{2 .1 蒸発残渣実験系}

各系列のpHの経時変化をFig. $5 、 \mathrm{~S}_{2} \mathrm{O}_{3}$ - $\mathrm{S}$ の酸化率及 び $\mathrm{SO}_{4}-\mathrm{S}$ 生成率をTable 6 に示す。塩類濃度 $12 \%$ の無 希釈系では、305時間の培養で、 $\mathrm{S}_{2} \mathrm{O}_{3}-\mathrm{S}$ が全量 $\mathrm{SO}_{4}-\mathrm{S}$

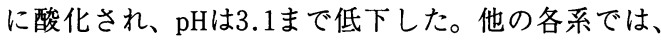
177時間の培養でONM対照系と同じく、 $\mathrm{S}_{2} \mathrm{O}_{3}-\mathrm{S}$ が全量 $\mathrm{SO}_{4}$-Sに酸化された。特に、10倍希釈 $(1.2 \%) 、 8$ 倍 
Table 5 Effect of GAC on acclimation ability of SOB inoculated into various dilutions of PW

\begin{tabular}{|c|c|c|c|c|c|c|c|c|c|c|}
\hline \multirow[b]{2}{*}{ Parameter } & \multicolumn{2}{|c|}{ 10-times dilu. } & \multicolumn{2}{|c|}{ 8-times dilu. } & \multicolumn{2}{|c|}{ 6-times dilu. } & \multicolumn{2}{|c|}{ 4-times dilu. } & \multicolumn{2}{|c|}{ 3-times dilu. } \\
\hline & GAC & No GAC & GAC & No GAC & GAC & No GAC & GAC & No GAC & GAC & No GAC \\
\hline $\operatorname{MLVSS}\left(\mathrm{mg} / l^{\mathrm{a}}\right.$ & 760 & 760 & 720 & 720 & 680 & 680 & 720 & 720 & 880 & 880 \\
\hline $\mathrm{S}_{2} \mathrm{O}_{3}-\mathrm{S}(\mathrm{mg} / \mathrm{l})^{\mathrm{a}}$ & 1,300 & 1,300 & 2,189 & 2,189 & 2,928 & 2,928 & 4,097 & 4,097 & 6,336 & 6,336 \\
\hline $\mathrm{SO}_{4}-\mathrm{S}(\mathrm{mg} / l)^{\mathrm{a}}$ & 640 & 640 & 170 & 170 & 1,057 & 1,057 & 1,523 & 1,523 & 2,399 & 2,399 \\
\hline Acclimation time (d) & 4.6 & 9.5 & 10.8 & 17.1 & 13.7 & 17.7 & 19.7 & - & 19.3 & - \\
\hline Rcsultant $\mathrm{SO}_{4}-\mathrm{S}(\mathrm{mg} / \mathrm{l})$ & 2,071 & 1,999 & 2,322 & 2,125 & 4,308 & 1,727 & 4,850 & - & 6,985 & - \\
\hline Oxidation rate $^{\mathrm{b}}(\%)$ & 110 & 104 & 98 & 89 & 111 & 23 & 82 & - & 72 & - \\
\hline Oxidation rate ${ }^{c}$ & 650 & 315 & 493 & 313 & 550 & - & 505 & - & 620 & - \\
\hline
\end{tabular}

${ }^{\text {a }}$ Initial value.

${ }^{b}$ Value indicates percent of thiosulfate completely oxidized to sulfate, i.e., the difference between the initial $\mathrm{SO}_{4}-\mathrm{S}^{2}$ and resultant $\mathrm{SO}_{4}-\mathrm{S}$ divided by the initial $\mathrm{S}_{2} \mathrm{O}_{3}-\mathrm{S}$.

${ }^{\mathrm{c}}$ Given as $\mathrm{mg} \mathrm{S}_{2} \mathrm{O}_{3}{ }^{2-} \cdot \mathrm{g} \mathrm{MLVSS}^{-1} \cdot \mathrm{d}^{-1}$.

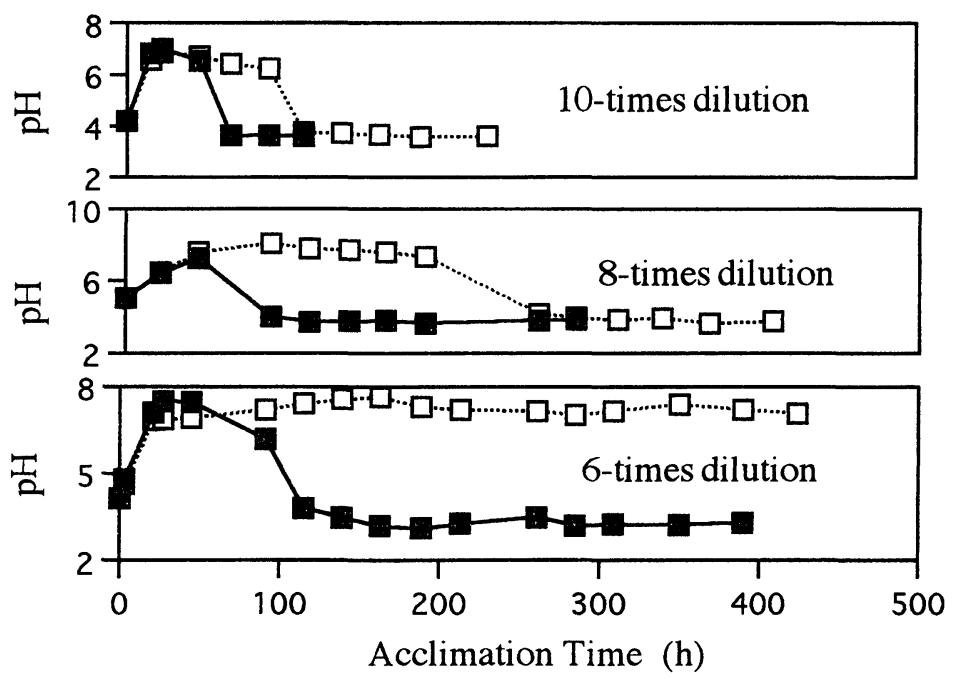

Fig. 3 Effect of GAC on $\mathrm{pH}$ during acclimation of $\mathrm{SOB}$ at indicated PW dilutions. Symbols : $\square$, with GAC; $\square$, without GAC

希釈 (1.5\%) の両系におけるpHはONM対照系と極めて 似た挙動であった（Fig. 5 )。この結果から、12\%とい う高塩類濃度の環境中において、SOB污泥の活性が若干 影響されたものの、増殖可能なことが明らかにされた。

\section{2 .2 無機塭成分実験系}

各系列のpHの経時変化をFig. 5 に示す。また、 $\mathrm{S}_{2} \mathrm{O}_{3}-\mathrm{S}$ 酸化率及び $\mathrm{SO}_{4}-\mathrm{S}$ 生成率（液中の $\mathrm{SO}_{3}-\mathrm{S}$ の酸化による $\mathrm{SO}_{4}$-Sの生成を差し引いた）をTable 7 に 示す。3.2.1と同じく、無希釈系（13.6\%）を除いた各
系では $\mathrm{S}_{2} \mathrm{O}_{3}-\mathrm{S}_{3}$ 全量 $\mathrm{SO}_{4}-\mathrm{S}$ 酸化され、そのpH変化 はONM対照系と似た挙動であった。無希釈系 (34, 120 $\mathrm{mg} / l$ の $\mathrm{S}_{2} \mathrm{O}_{3}{ }^{2-}$ 、かつ $13.6 \%$ 高塩類濃度）では、317時 間の培養で $\mathrm{S}_{2} \mathrm{O}_{3}-\mathrm{S}$ が全量 $\mathrm{SO}_{4}-\mathrm{S}$ に酸化され、 $\mathrm{pH}$ ガ3.5 まで低下した。従って、SOB污泥は高濃度の $\mathrm{S}_{2} \mathrm{O}_{3}{ }^{2-}$ を含 む高塩類濃度の環境中でも増殖可能なことが再び確認さ れた。

3.2.1および3.2.2との両実験系から、SOB污泥は高濃 度 $\mathrm{S}_{2} \mathrm{O}_{3}{ }^{2-}$ を含む高塩類濃度の廃液中に増殖可能なこと 

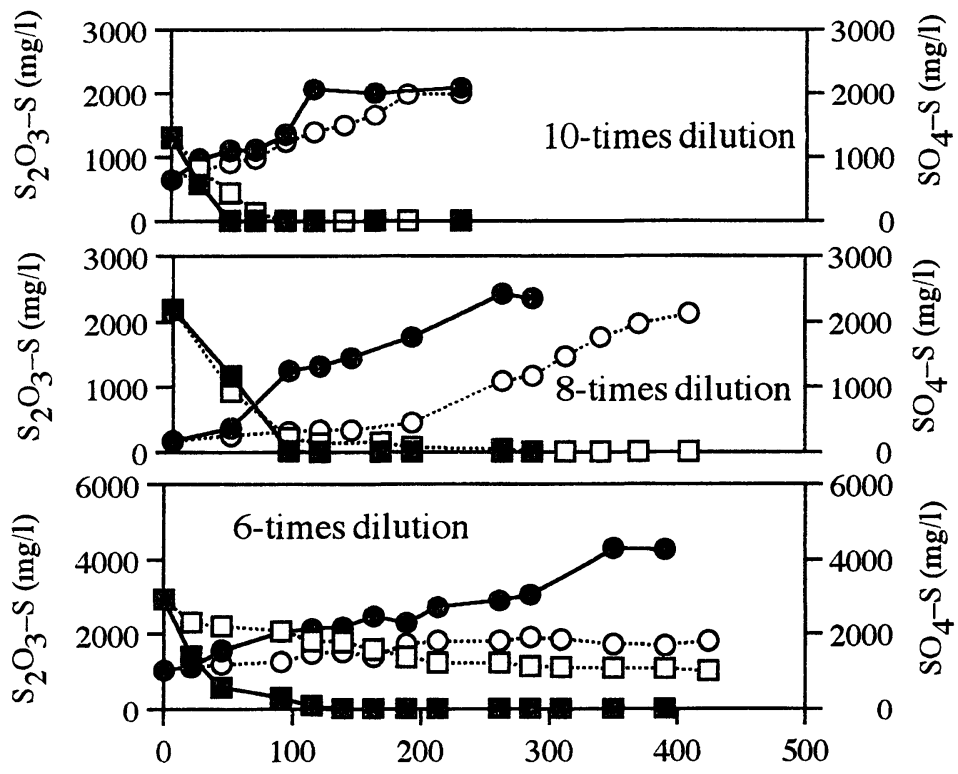

Acclimation Time (h)

Fig. 4 Effect of GAC on thiosulfate $\left(\mathrm{S}_{2} \mathrm{O}_{3}{ }^{2}\right)$ oxidation and sulfate $\left(\mathrm{SO}_{4}{ }^{2}{ }^{-}\right)$formation during acclimation of $\mathrm{SOB}$ at indicated PW dilutions. Symbols: $\mathbf{\square}$, with GAC/ $\mathrm{S}_{2} \mathrm{O}_{3}-\mathrm{S}$, O, with $\mathrm{GAC} / \mathrm{SO}_{4}-\mathrm{S}$, $\square$, without $\mathrm{GAC} /{ }_{2} \mathrm{O}_{3}-\mathrm{S}$, $\mathrm{O}$, without $\mathrm{GAC} /$ $\mathrm{SO}_{4}-\mathrm{S}$

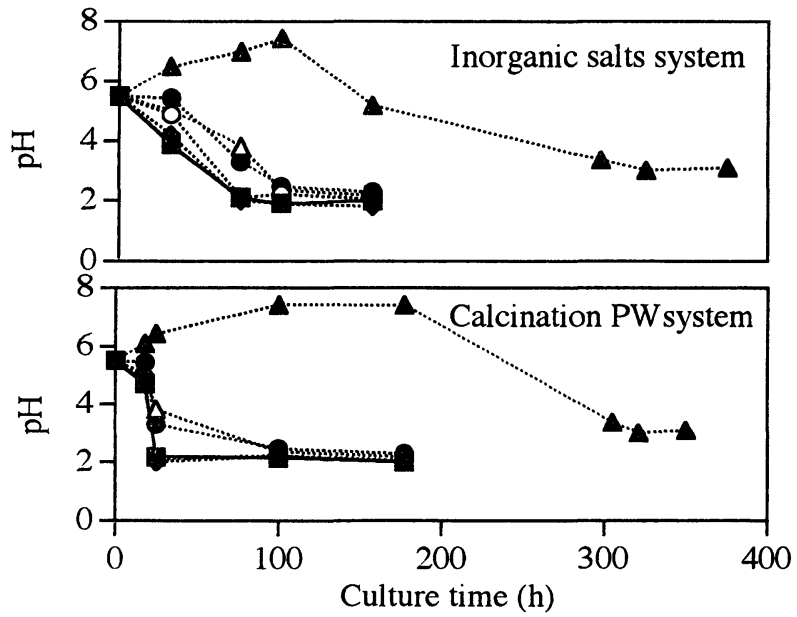

Fig. 5 Variations in $\mathrm{pH}$ of various dilutions in calcination $\mathrm{PW}$ sy stem and inorganic salts of composition in PW system. Symbols: $\square$, ONM ; $\diamond, 10$-times dilution; $\bigcirc$, 8times dilution; $\triangle$, 4-times dilution; 0 , 2-times dilution; $\Delta$, no dilution 
Table 6 Formation rates of $\mathrm{SO}_{4}-\mathrm{S}$ and oxidation rates of $\mathrm{S}_{2} \mathrm{O}_{3}-\mathrm{S}$ in various dilution series in calcination PW system during the culture

\begin{tabular}{cccccccc}
\hline $\begin{array}{c}\text { Culture } \\
\text { time }(\mathrm{hr})\end{array}$ & Compare items & $\begin{array}{c}\text { 1-times } \\
\text { dilution }\end{array}$ & $\begin{array}{c}2 \text {-times } \\
\text { dilution }\end{array}$ & $\begin{array}{c}4 \text {-times } \\
\text { dilution }\end{array}$ & $\begin{array}{c}\text { 8-times } \\
\text { dilution }\end{array}$ & $\begin{array}{c}\text { 10-times } \\
\text { dilution }\end{array}$ & $\begin{array}{c}\text { ONM } \\
\text { (control) }\end{array}$ \\
\hline & Salinity con. & $12.0 \%$ & $6.0 \%$ & $3.0 \%$ & $1.5 \%$ & $1.2 \%$ & - \\
26 & $\mathrm{SO}_{4}-\mathrm{S}^{2} \mathrm{~S}_{2} \mathrm{O}_{3}-\mathrm{S}$ & $18 / 85$ & $80 / 100$ & $35 / 97$ & $78 / 100$ & $83 / 100$ & $100 / 99$ \\
177 & $\mathrm{SO}_{4}-\mathrm{S} / \mathrm{S}_{2} \mathrm{O}_{3}-\mathrm{S}$ & $82 / 100$ & $135 / 100$ & $120 / 100$ & $124 / 100$ & $104 / 100$ & $116 / 100$ \\
305 & $\mathrm{SO}_{4}-\mathrm{S} / \mathrm{S}_{2} \mathrm{O}_{3}-\mathrm{S}$ & $115 / 100$ & - & - & - & - & - \\
\hline
\end{tabular}

Table 7 Formation rates of $\mathrm{SO}_{4}-\mathrm{S}$ and oxidation rates of $\mathrm{S}_{2} \mathrm{O}_{3}-\mathrm{S}$ in various dilution series in system of inorganic salts of composition from model PW during the culture

\begin{tabular}{cccccccc}
\hline $\begin{array}{c}\text { Culture } \\
\text { time }(\mathrm{hr})\end{array}$ & Compare items & $\begin{array}{c}\text { 1-times } \\
\text { dilution }\end{array}$ & $\begin{array}{c}2 \text {-times } \\
\text { dilution }\end{array}$ & $\begin{array}{c}4 \text {-times } \\
\text { dilution }\end{array}$ & $\begin{array}{c}\text { 8-times } \\
\text { dilution }\end{array}$ & $\begin{array}{c}\text { 10-times } \\
\text { dilution }\end{array}$ & $\begin{array}{c}\text { ONM } \\
\text { (control) }\end{array}$ \\
\hline & Salinity con. & $13.6 \%$ & $6.8 \%$ & $3.4 \%$ & $1.7 \%$ & $1.4 \%$ & - \\
32 & $\mathrm{SO}_{4}-\mathrm{S} / \mathrm{S}_{2} \mathrm{O}_{3}-\mathrm{S}$ & $21 / 87$ & $54 / 82$ & $88 / 99$ & $100 / 100$ & $95 / 100$ & $100 / 99$ \\
100 & $\mathrm{SO}_{4}-\mathrm{S} / \mathrm{S}_{2} \mathrm{O}_{3}-\mathrm{S}$ & $68 / 100$ & $99 / 100$ & $121 / 100$ & $112 / 100$ & $105 / 100$ & $100 / 100$ \\
156 & $\mathrm{SO}_{4}-\mathrm{S}_{\mathrm{S}_{2} \mathrm{O}_{3}-\mathrm{S}}$ & $79 / 100$ & $105 / 100$ & $119 / 100$ & $109 / 100$ & $114 / 100$ & $120 / 100$ \\
297 & $\mathrm{SO}_{4}-\mathrm{S} / \mathrm{S}_{2} \mathrm{O}_{3}-\mathrm{S}$ & $112 / 100$ & - & - & - & - & - \\
\hline
\end{tabular}

が確認された。しかし、完全にSO${ }_{4}{ }^{2-}$ まで酸化するには 長時間の処理を必要とするため、実際のプロセスでの処 理効率から見れば、希釈して処理する方が効率が良いと 思われる。また、GACを用いた馿養結果を考慮すると、 この高耐塩性のSOB污泥を用いた供試廃液処理では、污 泥の活性に阻害を与えたのは、現像主薬に含まれる阻害 性有機物質であることが示唆された。

\section{3. $3 \mathrm{SOB} / \mathrm{GAC}$ 系による供試廃液の連続処理}

98日間の連続処理における $\mathrm{S}_{2} \mathrm{O}_{3}{ }^{2-} 、 \mathrm{DOC} 、 \mathrm{COD}_{\mathrm{Mn}}$ の負 荷量、除去率及び供試廃液の希釈倍率、塩類濃度を Table 8に示す。槽中の $\mathrm{pH}$ 、流入廃液及び処理水中の $\mathrm{S}_{2} \mathrm{O}_{3}{ }^{2-} 、 \mathrm{DOC} 、 \mathrm{COD}_{\mathrm{Mn}_{\mathrm{n}}}$ の経時変化をFig. 6 に示す。

$5 〜 4$ 倍希釈廃液をHRT1.9 7.7日で98日間にわたっ て連続処理を行った。 $\mathrm{S}_{2} \mathrm{O}_{3}{ }^{2}{ }^{2-}$ の負荷量は0.8 3.7 $\mathrm{kg} / l / \mathrm{d} て ゙ 、 97 \% \sim 100 \% の$ 酸化率が得られ、その平均酸 化率は100\%であった。また、イオンクロマトグラフ分 析の結果から、 $\mathrm{S}_{2} \mathrm{O}_{3}-\mathrm{S}$ が全量 $\mathrm{SO}_{4}$-Sに酸化されたこと も確認された。アルカリ性の流入廃液は生成した硫酸に より、槽中の $\mathrm{pH}$ が常に酸性側の3.8 4.5の間に保持さ れた。
また、この連続処理では供試廃液中の $\mathrm{S}_{2} \mathrm{O}_{3}{ }^{2-}$ のよう な還元性硫黄化合物が酸化されたと同時に、DOCも除去 された。DOCの負荷量は $0.5 \sim 1.8 \mathrm{~kg} / l / \mathrm{d}$ で38.6\% $62.0 \%$ の除去率が得られ、その平均除去率は $55 \%$ であっ た。また、 $\mathrm{COD}_{\mathrm{Mn}}$ の除去については、負荷量0.8 3.1 $\mathrm{kg} / \mathrm{l} / \mathrm{d}$ で、 $44.8 \% \sim 75.0 \%$ の除去率が得られ、その平均 除去率は $68.0 \%$ であった。

98日間の連続処理の経験から、高い負荷量での連続処 理では、高い曝気量を維持することが重要である。しか し、供試廃液中には界面活性剂（Table 1）などの物質 が含まれているため、曝気と共に泡が生じ、高い曝気量 の維持は困難であった。ただし、消泡剤の検討は行われ ていない。

\section{47 種類の選択培地を用いたSOB污泥の単離結果}

連続処理の結果から、 $\mathrm{S}_{2} \mathrm{O}_{3}{ }^{2}{ }^{2}$ が100\%酸化されたと同 時に、供試廃液中のDOCも平均 $55 \%$ 除去されたことが分 かった。このような高塩類、高CODの供試廃液中に増殖 可能な $\mathrm{SOB}$ は、 $\mathrm{S}_{2} \mathrm{O}_{3}{ }^{2-}$ を酸化すると同時に廃液中の易分 解性有機物質をも分解したと予想された。 $\mathrm{S}_{2} \mathrm{O}_{3}{ }^{2-}$ を酸 化可能な細菌はSOBの他に、土壤から単離した従属栄養 細菌もこの酸化能力を有している ${ }^{27)}$ 。SOBについては、 
Table 8 Volume load and the removal rates of thiosulfate $\left(\mathrm{S}_{2} \mathrm{O}_{3}{ }^{2}\right)$, DOC, and COD during long-term, continuous treatment by the aerobic SOB/GAC system

\begin{tabular}{c|c|c|c|c|c}
\hline $\begin{array}{c}\text { Period } \\
(\mathrm{d})\end{array}$ & $\begin{array}{c}\text { Dilu. times } \\
\text { Salinity con. }\end{array}$ & $\begin{array}{c}\mathrm{HRT} \\
\text { (d) }\end{array}$ & $\begin{array}{c}\mathrm{S}_{2} \mathrm{O}^{2}{ }^{2-}(\mathrm{kg} / l / \text { day }) / \\
\text { Removal rate (\%) }\end{array}$ & $\begin{array}{c}\text { DOC }(\mathrm{kg} / l / \text { day }) / \\
\text { Removal rate }(\%)\end{array}$ & $\begin{array}{c}\text { COD }(\mathrm{kg} / l / \text { day }) / \\
\text { Removal rate }(\%)\end{array}$ \\
\hline $0.0 \sim 8.2^{*}$ & $8 / 1.5 \%$ & 9.6 & $0.4 / 100$ & $0.3 / 62.0$ & $0.6 / 75.0$ \\
$8.2 \sim 14.0$ & & 4.8 & $0.8 / 100$ & $0.5 / 62.0$ & $1.2 / 75.0$ \\
\hline $14.0 \sim 35.0$ & $5 / 2.4 \%$ & 7.7 & $0.8 / 100$ & $0.5 / 59.5$ & $0.8 / 69.1$ \\
$35.0 \sim 47.9$ & & 5.7 & $1.1 / 100$ & $0.6 / 59.0$ & $1.1 / 71.6$ \\
$47.9 \sim 63.9$ & & 2.8 & $2.7 / 100$ & $1.3 / 59.2$ & $2.5 / 72.8$ \\
$63.9 \sim 72.9$ & & 1.9 & $3.7 / 97$ & $1.8 / 53.3$ & $3.0 / 67.6$ \\
\hline $72.9 \sim 85.9$ & $4 / 3.0 \%$ & 5.9 & $1.6 / 100$ & $0.7 / 49.5$ & $1.5 / 64.5$ \\
\hline $85.9 \sim 97.9$ & & 3.5 & $2.6 / 100$ & $1.3 / 38.6$ & $3.1 / 44.8$ \\
\hline
\end{tabular}

*Indicates as reference data due to the initial period of the continuous treatment.

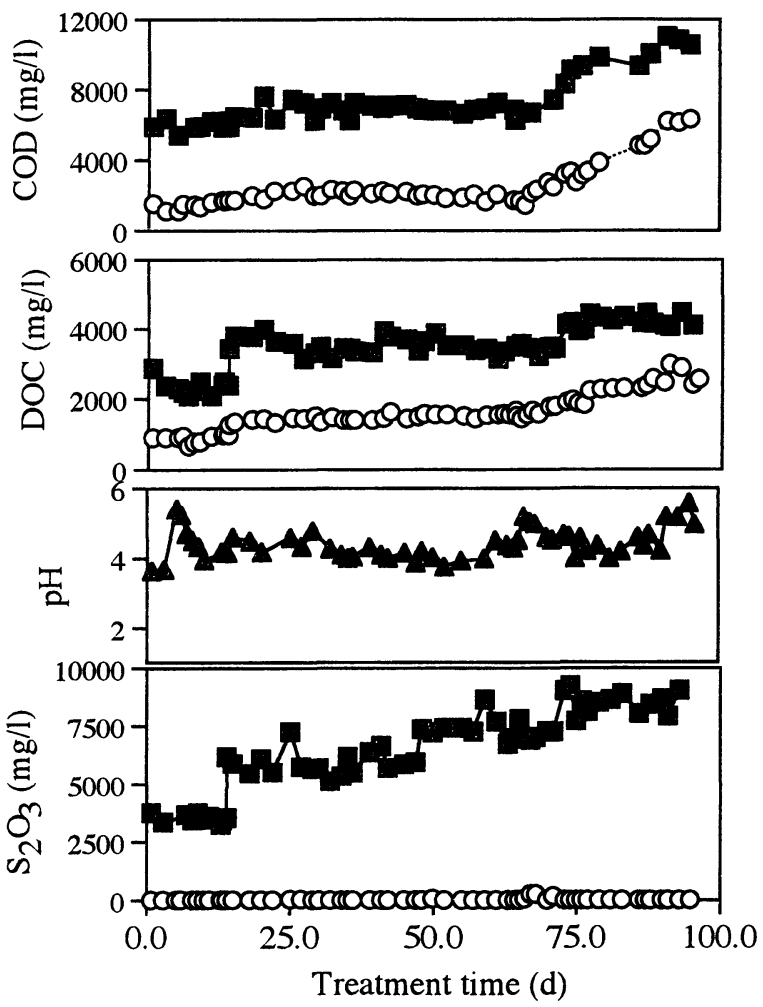

Fig. 6 Variations in $\mathrm{S}_{2} \mathrm{O}_{3}{ }^{2-}$, reactor $\mathrm{pH}, \mathrm{DOC}$ and $\mathrm{COD}$ in influent and effluent during continuous treatment. Symbols : $\boldsymbol{\square}$, influent; $\bigcirc$, effluent; $\Delta$, reactor pH 
古くから化学独立栄養細菌群に属するとされている。そ の栄養性から更に絶対化学独立栄養細菌、通性化学独立 栄養細菌と混合性化学独立栄養細菌に分けられる

単離実験に使われた 7 種類の培地、及びSOB污泥を単 離した結果をTable 4に示した。コロニーAはNo.1の 無機培地のみならず（ONM培地中の有機物質を除いた 無機成分のみ)、有機物質を加えたNo. 2, 3，4の培地 にも増殖可能であったことから、コロニーAは通性化学 独立栄養のSOBであることが分かった。コロニーB、C はNo. 1 の無機培地を除いて、他の 6 種類の培地で増殖 可能であったことから、 $\mathrm{S}_{2} \mathrm{O}_{3}{ }^{2-}$ の酸化が可能な従属栄 養細菌であると思われた。特にコロニーBは独特なピン ク色のコロニーであった。また、コロニーの数の計数に よって、約 $90 \%$ のコローがAであったことから、この 污泥は主に通性化学独立栄養のSOBであることが明らか にされた。

\section{4. まとめ}

除去効率の良い、コストの安い、実用性の高い陸上に おける写真廃液処理プロセスの研究開発を目指し、化学 処理の前段としてSOBを用いた生物処理についての検討 を行った本研究では、以下の結果が得られた。

1. 培地系と廃液系との両系列を用いた馴養では、両系 とも12倍希釈廃液の馴養まで順調に行われたが、両系 の間に有意な差は認められなかった。

2. 供試廃液中の阻害性有機物質は活性炭に吸着された ため、SOB/GAC系では 3 倍希釈廃液までの馴養が認 められたことに対して、SOB系では 6 倍希釈廃液での 馴養は認められなかった。

3. $\mathrm{SOB}$ 污泥は高濃度の $\mathrm{S}_{2} \mathrm{O}_{3}{ }^{2-}$ を含む高塩類濃度の供試 廃液中にも増殖可能なことが確認された。

4. 得られたSOB污泥による連続処理は98日間安定して 行われた。 4 〜 倍希釈廃液をHRT1.9〜7.6日で運転 した結果、 $\mathrm{S}_{2} \mathrm{O}_{3}{ }^{2}$ - が完全に酸化されたと同時に、 DOCの除去率は平均 $55 \%$ 、 $\mathrm{COD}_{\mathrm{Mn}}$ は平均 $68 \%$ であった。

5. 7 種類の選択培地による污泥のSOB単離実験から、 約90\%のコロニーは通性化学独立栄養のSOBで、 $\mathrm{S}_{2} \mathrm{O}_{3}{ }^{2-}$ を酸化可能な従属栄養細菌も 2 種類共存して いることが確認された。

このように、写真廃液中の大量の $\mathrm{S}_{2} \mathrm{O}_{3}{ }^{2-}$ p $\mathrm{SO}_{3}{ }^{2-}$ うな還元性物質、及び易分解性の有機物質は先にSOB污 泥により効率よく酸化処理できたため、それに続くフェ ントン処理での $\mathrm{H}_{2} \mathrm{O}_{2}$ の使用量が大幅に削減できるとと
もに、突沸の危険性の克服にも大いに期待できる。

\section{参考文献}

1）竹内正美、村上定瞭、深川勝之、中西弘、北尾高嶺 : 写真廃液中の生物難分解性物質のオゾン処理、環 境工学研究論文集、30、175-186(1993).

2) Binle Lin, Futono K., Yokoi A., Hosomi M., Murakami A.: Effects of Activated Carbon on Treatment of Photo-Processing Waste by SulfurOxidizing Bacteria. Wat. Sci. Tech., 35(7), 187195(1997).

3 ）太野公人、林涁勒、横井业希、細見正明、村上昭彦 : 高濃度COD、アンモニア性窒素を含む写真廃液の 処理プロセスに関する研究、廃棄物学会誌、8(7)、 303-310 (1997).

4 ）竹内正美、深川勝之、品川恵美子、村上定瞭、浮田 正夫、中西弘：写真廃液処理プロセスの開発に関す る研究（膜分離高濃度活性污泥法よる 1 次生物処 理）、衛生工学論文集、27、183-193(1991)。

5 ）伊永隆史、竹内文章、黒瀬節夫、明道勉、高橋照男 : フェントン法による写真廃液の酸化分解、水質污 濁研究、12(4)、233-238 (1989)

6 ) 五嶋伸隆 : 写真廃液の蒸発濃縮処理システム一発生 源における減量化事例一、廃棄物学会誌、4(3)、 221-237 (1993).

7 ) 岡山大学環境管理センター：環境資源科学研究成果 集、1、(1987)

8) K. W. Ragland, C. E. Holm, A. W. Andren : Laboratory investigation of incineration of spent photofinishing liquids, SPSE 5th Intermational Symp. on Photofinishing Technology, (1990).

9) Venkatadri R., Peters R. W.: Chemical Oxidation Technologies (Ultraviolet Light/Hydrogen Peroxide, Fenton's Reagent, and Titanium Dioxide-Assisted Photocatalysis). Hazardous Waste \& Hazardous Materials, 10, 107-149(1993).

10）黑川利一、石原豊、中嶋良三：写真工業廃液の処理 （ I ）COD低減のための基礎実験、水処理技術、28、 75-81 (1987).

11）横井亜希、太野公人、林涁勒、細見正明、村上昭彦 : 写真廃液中に含まれる成分のフェントン処理及び 生分解性の評価、廃棄物学会誌、棄物学会誌、8(7)、 342-347 (1997)

12) T. W. Bober and T. J. Dagon: Ozonation of photographic processing wastes, JWPCF, 8, 21142129(1975).

13）岩野治彦、松下幸雄、石川強、井上仁一郎：写真廃 液処理に対するオゾンの適用の研究 (I) 処理液成分 のオゾン分解の挙動、日本写真学会誌、39、 131-138(1976).

14) Pavlostathis S. G., Sridhar K. : Treatment of 
Photoprocessing Effluents by the Activated Sludge Process. J. of Imag. Sci. and Techn., 36, 405-411 (1992).

15) Pavlostathis S. G., Morrison D.: Response of continuous-flow activated sludge reactors to photoprocessing wastewaters. Water Res., 28, 269 -276(1993).

16) Pavlostathis S. G., Morrison D.: Aerobic Biodegradation Potential of Photoprocessing Wastewater. Water Environs. Res., 66, 211-219 (1994).

17）城田久岳、岸野拓男、浮田正夫、中西弘：生物活性 炭による写真廃液の処理、水質污濁研究、14 (10)、 700-708(1991).

18) T. J. Dagon: Biological Treatment of Photo Processing Effluents, JWPCF, 45, 2123-2135 (1973).

19）竹内正美、深川勝之、村上定瞭、浮田正夫、中西弘 : 浸積ろ床法による写真廃液処理に関する研究、環 境技術、19、328-330(1990).

20）中島良三、石原豊、黒川利一、古川正道、田中一彦、 中島邦雄 : 写真工業廃液の処理（定着及び現像廃 液のシステムについて)、水処理技術、30(8)、
457-465(1989).

21) Waksman, S. A., Joffe, J. S: J. Bacterial, 7, 239243(1922).

22) Schultz J. R., Keinath T. M.: Powdered Activated Carbon Treatment Process Mechanisms. JWPCF, 56, 143-150(1984).

23) Speitel jr. G. E., Lu C. J., Zhu X. J., Turakhia M. $\mathrm{H}$. : Biodegradation and Adsorption of a Bisolute Mixture in GAC Columns. JWPCF, 61, 221-229 (1989).

24) Sublette K. L., Snider E. H., Sylvester N. D.: A Review of the Mechanism of Powdered Activated Carbon Enhancement of Activated Sludge Treatment. Water Res., 16, 1075-1082(1982).

25）谷口日出雄、西嶋渉、村上昭彦、岡田光正、細見正 明：PAC添加活性污泥法における活性炭の効果、水 環境学会誌、16(8)、577-584 (1993).

26）日本下水道協会：下水試験方法 1984年版

27) Vishniac W., Santer M.: The Thiobacilli. Bacterial. Rev., 21, 195-213(1957).

（受付 1997.9.8) (受理 1997. 11. 22) 